This item was submitted to Loughborough's Research Repository by the author.

Items in Figshare are protected by copyright, with all rights reserved, unless otherwise indicated.

\title{
Co-designing with children a collaborative augmented reality book based on a primary school textbook
}

PLEASE CITE THE PUBLISHED VERSION

https://doi.org/10.1016/j.ijcci.2017.11.005

\section{PUBLISHER}

(C) Elsevier

VERSION

AM (Accepted Manuscript)

\section{PUBLISHER STATEMENT}

This work is made available according to the conditions of the Creative Commons Attribution-NonCommercialNoDerivatives 4.0 International (CC BY-NC-ND 4.0) licence. Full details of this licence are available at: https://creativecommons.org/licenses/by-nc-nd/4.0/

\section{LICENCE}

CC BY-NC-ND 4.0

\section{REPOSITORY RECORD}

Alhumaidan, Haifa, Kathy Pui Ying Lo, and Andrew Selby. 2019. "Co-designing with Children a Collaborative Augmented Reality Book Based on a Primary School Textbook”. figshare. https://hdl.handle.net/2134/31999. 


\title{
Co-designing with Children a Collaborative Augmented Reality Book Based on a Primary School Textbook
}

\author{
Haifa Alhumaidan \\ Loughborough University, Corresponding Author \\ Epinal Way, Loughborough \\ Leicestershire, UK \\ LE11 3TU \\ H.Alhumaidan@lboro.ac.uk \\ Kathy Pui Ying Lo \\ Loughborough University \\ Epinal Way, Loughborough \\ Leicestershire, UK \\ LE11 3TU \\ K.P.Y.Lo@1boro.ac.uk \\ Andrew Selby \\ Loughborough University \\ Epinal Way, Loughborough \\ Leicestershire, UK \\ LE113TU \\ A.Selby@lboro.ac.uk
}

\begin{abstract}
Augmented Reality (AR) ${ }^{1}$ has been proven to support collaboration when used in different contexts. AR Books have been developed for children in different contexts including entertainment and education. However, the involvement of children in designing AR Books based on the actual school textbooks has not been covered previously. This paper presents codesign process of involving primary school children in the design and evaluation of an AR textbook for collaborative learning experience. Using cooperative inquiry techniques as an appropriate method of co-design with children, this paper proposes the key design features that can be integrated in the school textbook for a collaborative AR textbook.
\end{abstract}

\section{Keywords}

Cooperative Inquiry Techniques; Co-design; Augmented Reality; Textbook; Collaborative Learning Experience; Child-Computer Interaction;

\footnotetext{
${ }^{1}$ Augmented Reality.

${ }^{2}$ Cooperative Inquiry Critiquing

${ }^{3}$ Participatory Design.

${ }^{4}$ Child Computer Interaction.
} 


\section{INTRODUCTION}

Augmented Reality provides a great potential for learning, however, "The matter is not questioning whether AR is useful to enhance learning. The matter is to understand how to effectively exploit its potential" [1]. Specifically, textbook-based AR allows multiple students to share the virtual scene, and interact with it through the tablet interface as a hand-held display. One of the important aspect of learning is students' collaboration [2], and one of the great potential of AR is that it supports collaborative experiences [3]. AR can be used to create a unique collaborative experience [4], [5], [6], however, this unique collaborative experience is not created by the AR technology, it is rather created by the potential features that are implied in the design of the application [7]. While students' collaboration is effective for the co-construction of knowledge, this concept is not guaranteed with 'merely' putting students together in groups [8]. There is a need of studies that extends the understanding of how specific technologies such as AR may support collaboration between children in the educational context [9]. A recent survey of the status of AR in education has recommended highlighting the features of $A R$ to reveal educational values unique to $A R$, in addition to exploring the solutions for integrating these features into regular school curriculums [10].

In this respect, it was aimed to identify the design features specific to $A R$ affordances that can be implied in the textbooks to for collaborative learning experience in primary schools. This was done through a process of co-design with children to find out these design features and implement them in an AR textbook prototype. A set of techniques called 'cooperative inquiry' was adopted to involve primary school children with adults from different academic backgrounds in the co-design process [11]. The three selected techniques of cooperative inquiry are 'Low-tech prototyping' which is a cooperative inquiry technique used for the early stage of designing an interactive technology with children [12]. The second is 'Sticky Noting' [13] which is a cooperative inquiry technique for critiquing a prototype with children, and will be called (CI critiquing) ${ }^{2}$ in this paper. 'Layered elaboration' technique was also used as a generative method to support the CI critiquing [14].

In this paper, we introduce the methodological framework of the co-design study. Then we describe the two phases of the study that involve 8-10 years old children and adults in codesigning the collaborative AR textbook. The first phase is low-tech prototyping which gave an overall direction of designing the first AR textbook prototype. The second phase is a

\footnotetext{
${ }^{2}$ Cooperative Inquiry Critiquing
} 
formative evaluation that used cooperative inquiry critiquing and layered elaboration which resulted in the design features to be implemented in the second AR textbook prototype. We then propose the key design features that can be integrated in the school textbook for a collaborative AR textbook. Finally, we reflect on the findings upon related work, and provide implications of our research.

\section{RELATED WORK AND BACKGROUND METHODS}

Co-design was considered to allow children voices in the design of their AR textbook [15]. Three methodological considerations have been adopted to inform the co-design process which has been documented in a way that can provide a practical implication of co-designing a children's collaborative AR textbook. These considerations are grounded in (PD) ${ }^{3}$ and $(\mathrm{CCI})^{4}$.

- Sanders and Stappers' co-design framework [16], [17] to inform the planning stage.

The comparison questions in Table 1 were used as a helpful guide to organise the toolkits in the co-design sessions used specifically for AR Books.

Table 1: A Comparison of The Three Approaches To Making [16].

\begin{tabular}{|c|c|c|c|}
\hline & Probes & Toolkits & Prototypes \\
\hline $\begin{array}{l}\text { What is } \\
\text { made? }\end{array}$ & $\begin{array}{l}\text { Probes are materials } \\
\text { that have been } \\
\text { designed to provoke or } \\
\text { elicit response. For } \\
\text { example, a postcard } \\
\text { without a message. }\end{array}$ & $\begin{array}{l}\text { Toolkits (made up of a } \\
\text { variety of components) are } \\
\text { specifically confirmed for } \\
\text { each project/domain. } \\
\text { People use the toolkit } \\
\text { components to make } \\
\text { artefacts about or for the } \\
\text { future. }\end{array}$ & $\begin{array}{l}\text { Prototypes are physical } \\
\text { manifestations of ideas or } \\
\text { concepts. They range from } \\
\text { rough (giving the overall } \\
\text { idea only) to finished } \\
\text { (resembling the actual end } \\
\text { result). }\end{array}$ \\
\hline Why? & $\begin{array}{l}\text { Designers find } \\
\text { inspiration in users' } \\
\text { reactions to their } \\
\text { suggestions. }\end{array}$ & $\begin{array}{l}\text { To give non-designers a } \\
\text { means with which to } \\
\text { participate as co-designers } \\
\text { in the design process. }\end{array}$ & $\begin{array}{l}\text { To give form to an idea, and } \\
\text { to explore technical and } \\
\text { social feasibility. }\end{array}$ \\
\hline What is & $\begin{array}{l}\text { Probes can take on a } \\
\text { wide variety of forms }\end{array}$ & $\begin{array}{l}\text { Toolkits are made of } 2 \mathrm{D} \text { or } \\
3 \mathrm{D} \text { components such as }\end{array}$ & $\begin{array}{l}\text { Prototypes can be made } \\
\text { from a very wide array of }\end{array}$ \\
\hline
\end{tabular}

\footnotetext{
${ }^{3}$ Participatory Design.

${ }^{4}$ Child Computer Interaction.
} 


\begin{tabular}{|l|l|l|l|}
\hline $\begin{array}{l}\text { made out } \\
\text { of? }\end{array}$ & $\begin{array}{l}\text { such as diaries, work- } \\
\text { books, cameras with } \\
\text { instructions, etc. }\end{array}$ & $\begin{array}{l}\text { pictures, words, phrases, } \\
\text { blocks, shapes, buttons, } \\
\text { pipe cleaners, wires, etc. }\end{array}$ & $\begin{array}{l}\text { materials including clay, } \\
\text { foam, plastic, simple digital } \\
\text { and electronic elements. }\end{array}$ \\
\hline $\begin{array}{l}\text { Who } \\
\text { conceives? }\end{array}$ & $\begin{array}{l}\text { Designers create the } \\
\text { probes and send them } \\
\text { to end-users and other } \\
\text { stakeholders, often } \\
\text { with little or no } \\
\text { guidance of how the } \\
\text { end-users should treat } \\
\text { them. }\end{array}$ & $\begin{array}{l}\text { Designers and researchers } \\
\text { make the toolkits and give } \\
\text { them to others to use to } \\
\text { make artefacts. The process } \\
\text { is often facilitated or guided. }\end{array}$ & $\begin{array}{l}\text { Co-designers create the } \\
\text { prototypes to envision their } \\
\text { ideas and to display and to } \\
\text { get feedback on these ideas } \\
\text { from other stakeholders. }\end{array}$ \\
\hline Who uses? & $\begin{array}{l}\text { End-users and other } \\
\text { stakeholders } \\
\text { individually complete } \\
\text { the probes, returning } \\
\text { them to the person who } \\
\text { sent them out. }\end{array}$ & $\begin{array}{l}\text { End-users and other } \\
\text { stakeholders use them to } \\
\text { make artefacts about or for } \\
\text { the future. Toolkits work } \\
\text { with both individuals and } \\
\text { small groups. }\end{array}$ & $\begin{array}{l}\text { pesigners use the } \\
\text { prototypes as design tools. } \\
\text { End-users may use the } \\
\text { Prototypes during } \\
\text { evaluative research events. }\end{array}$ \\
\hline
\end{tabular}

- Druin's cooperative inquiry techniques, to inform the data collection procedures " [12]. "Cooperative inquiry offers a set of techniques that can be used by teams of adults and children together throughout the design process" [12]. It is considered as a common method used in the intergenerational co-design process [18], to enable children and adults to work together to create innovative technology for children, and is grounded in the participatory design approach [14].

A technique was defined by as "a creative endeavor that is meant to communicate design ideas and system requirements to a larger group" [19]. The application of a technique can be very brief in one or two design sessions, such as cooperative inquiry techniques. While they defined a method as a "collection of techniques used in conjunction with a larger design philosophy" [19]. Therefore, a method such as co-design unifies multiple techniques such as cooperative inquiry techniques within a larger design philosophy which is PD. Low-tech prototyping was selected for the early stage of the design. Based on the outcome of the first study, a high-fidelity prototype of the AR textbook has been developed for the next formative evaluation study. Cooperative inquiry critiquing and layered elaboration techniques has been carried out as a formative evaluation after six months of the first study. 
Thematic analysis was used as a method for identifying patterns in the dataset since it relies on visualisation on the form of placing the data on the wall or whiteboard [16]. This type of analysis is best suited the data collection methods; in this instance, cooperative inquiry which requires the dataset to be placed on the whiteboard to help the team to follow the progress, and contribute to the discussion and decisions. This method permits all the team members from the different backgrounds to visualise, reflect on and contribute to the analysis process. Human Computer Interaction studies follow a set of well-developed procedures for analysing text content to ensure accuracy and consistency of the thematic analysis. Solid thematic analysis depends on accurately identified concepts that later serve as categories for which data are sought and in which data are grouped [20]. It can be undertaken with only one researcher, but the chance for objective interpretations of the data set will be higher when a team of experts are involved in the analysis. It should be noted that this research takes into account these procedures and techniques to ensure systematic analysis in its studies.

- McKnight and Reads' 'play, learn, use' model [21], this model was based on the three genres of children's interactive technologies, and was proposed as a key tool to assist in understanding and defining how children interact with technology [22]. It was adopted in this study to inform the concepts to be used in the analysis process as a classification framework needed for the thematic analysis.

The thematic analysis "involves interacting with data, making comparisons between data, and so on, and in doing so, deriving concepts to stand for those data, then developing those concepts in terms of their properties and dimensions", [23]. In open coding, the coding categories come from the 'researcher-denoted concepts' which are the concepts identified by the researcher to describe the interesting and pertinent instances that emerge from the data [23]. These concepts are Experience, Learn, Use, in which the Experience was suggested as an encompassing concept that can include the aspects of wide range of experiences that children's interactive technologies can be designed for, including 'play', and collaboration as in this study.

\section{LOW-TECH PROTOTYPING OF THE AR TEXTBOOK}

\subsection{Participants}

The children who participated in the research were four males, and five females of the age group 8 - 10 years approached from different primary schools in Saudi Arabia. They all study 
the same textbook used in the study, and are familiar with tablets, and children's tablet applications. The three adult participants have different academic background, including one teacher of a Saudi primary school, an HCI expert, and a university lecturer qualified in children's psychology. The same participants are involved in each session of the study as codesigners, and are the same participants in the next phase of the study. A set of protocols has been indicated for the adult participants to ensure a level of consistency in the outcomes (Table 2).

Table 2: The set of protocols of low-tech prototyping

\begin{tabular}{|c|c|c|c|c|}
\hline \multirow{2}{*}{\multicolumn{3}{|c|}{$\begin{array}{l}\text { The objective } \\
\text { The aim is to brainstorm design ideas of the } \\
\text { AR textbook interface that support students' } \\
\text { collaboration. The generated outcomes aim to } \\
\text { envision the co-designers' ideas and to get } \\
\text { feedback on these ideas. }\end{array}$}} & \multicolumn{2}{|l|}{ The expected outcome } \\
\hline & & & \multicolumn{2}{|c|}{$\begin{array}{l}3 \text { models of low-tech prototypes of the } \mathrm{AR} \\
\text { textbook interface. The models are made up of a } \\
\text { variety of components using the toolkits provided. } \\
\text { The prototypes are physical manifestations of the } \\
\text { groups' ideas. }\end{array}$} \\
\hline \multicolumn{5}{|l|}{ The role } \\
\hline Children & \multicolumn{2}{|c|}{$\begin{array}{l}\text { Creator: Creating the prototypes } \\
\text { from the provided toolkit. }\end{array}$} & \multicolumn{2}{|c|}{$\begin{array}{l}\text { Presenter: Presenting the group's low-tech } \\
\text { prototype to the whole team. }\end{array}$} \\
\hline Adults & \multicolumn{2}{|c|}{$\begin{array}{l}\text { Facilitator: Facilitating the } \\
\text { collaborative work in creating } \\
\text { the prototypes. }\end{array}$} & $\begin{array}{l}\text { Note takers: Guidelines are } \\
\text { listed below. }\end{array}$ & \multirow{2}{*}{$\begin{array}{l}\text { Coder: } \\
\text { Participating in the } \\
\text { process of the } \\
\text { thematic analysis. }\end{array}$} \\
\hline & \multicolumn{2}{|c|}{$\begin{array}{l}\text { Observer: Floating from group } \\
\text { to group to get an overall feel of } \\
\text { the directions that the groups are } \\
\text { headed. }\end{array}$} & $\begin{array}{l}\text { Note taker: Review the } \\
\text { ideas with the groups and } \\
\text { check no important ideas }\end{array}$ & \\
\hline \multicolumn{5}{|c|}{ ing guidelines } \\
\hline \multirow{4}{*}{\multicolumn{2}{|c|}{$\begin{array}{l}\text { In addition to facilitating the activity, } \\
\text { adult members will contribute in the } \\
\text { data collection process. While the } \\
\text { final prototype is important, the } \\
\text { building of the model and the } \\
\text { discussion and elaboration that occur } \\
\text { around the prototype are as } \\
\text { important. }\end{array}$}} & \multirow{2}{*}{\multicolumn{3}{|c|}{$\begin{array}{l}\text { Writing short text descriptions of conversations that occur } \\
\text { during the brainstorming process. } \\
\text { Notes of the dialogues that occur during the activity } \\
\text { (making process) as the resulting prototype may not } \\
\text { represent all of the ideas expressed in the verbal discussion. }\end{array}$}} \\
\hline & & & & \\
\hline & & \multicolumn{3}{|c|}{$\begin{array}{l}\text { Notes concerning children's impressions can also be } \\
\text { written. }\end{array}$} \\
\hline & & \multicolumn{3}{|c|}{$\begin{array}{l}\text { There are no right or wrong in note taking, the aim is to } \\
\text { provide rich content for the directions of the design. }\end{array}$} \\
\hline
\end{tabular}




\subsection{Materials}

Based on Sanders and Stappers' framework, Table 3 shows the toolkit used in the low-tech prototyping of the AR textbook, clarifying their purposes and the roles of co-designers related to these toolkits. The use of probes can be represented in the adult's facilitation dialogues during the session, that will be shown in Table 5. The actual toolkit being used in the session can be seen in Figure 1.

Table 3: Planning the first co-design session based on Sanders and Stappers' questions.

\begin{tabular}{|l|l|}
\hline Questions & Toolkit \\
\hline What is made? & $\begin{array}{l}\text { The actual AR interface opens the camera to show the real world and } \\
\text { track any AR markers. Therefore, an initial tablet template made of } \\
\text { transparent thick plastic material with a tablet frame is created for the } \\
\text { children to build their low-tech prototypes on it. }\end{array}$ \\
\hline Why? & $\begin{array}{l}\text { The tablet serves as the main elements for co-design activity, to give } \\
\text { the participants the sense of the tablet to build on, and to help imagine } \\
\text { the AR interface, which will turn on the camera directly to show the } \\
\text { real world behind. }\end{array}$ \\
\hline What is it made out of? & $\begin{array}{l}\text { The interface elements are printed on pieces of paper to let users build } \\
\text { their ideal interface out of these initial parts. Pieces of UI elements, } \\
\text { different sizes and shapes of post-it notes, pipe cleaners, strings, cotton } \\
\text { balls, foam balls, scissors, glues, erasable coloured markers. }\end{array}$ \\
\hline Who conceives? & $\begin{array}{l}\text { The researcher made the initial template of the tablet, and provides the } \\
\text { toolkits to the participants to make artefacts. The process is facilitated } \\
\text { and guided by the researcher and the adult members. }\end{array}$ \\
\hline Who uses? & $\begin{array}{l}\text { The three groups of children and adult members use the toolkits to } \\
\text { generate ideas, and create three low-tech prototypes of the AR Book. }\end{array}$ \\
\hline
\end{tabular}
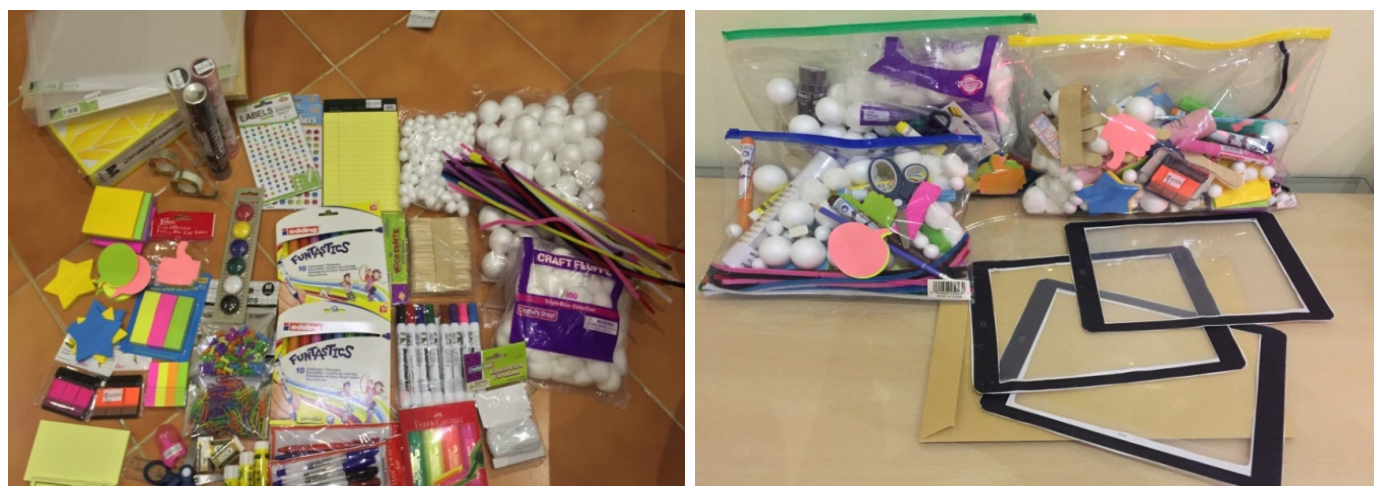

Figure 1: The toolkits and the created tablet templates to simulates the AR interface. 


\subsection{Procedure}

The participants were divided into 3 groups of 3 children and 1 adult (Figure 2). The researcher proposed the idea of the AR textbook, and explained the aim of the intended project. An example of AR books was presented by video clips to the whole group in order familiarise them with the idea of this new technology. Each group was given the toolkit to make a model for the AR textbook. Throughout this process adult members were taking notes of the dialogue between children while making the artefacts. After that, each group presented their model and discussed it with the whole team, while the researcher was taking notes of the key ideas on the white board. The researcher wrote the ideas on the white board and checked with the groups that there were no important ideas are missed. Finally, the ideas on the white board were discussed with the adult members to evaluate and compare with notes taken through the session. Thematic analysis was used to find patterns and generate the design themes for an overall direction of designing the first AR textbook prototype.

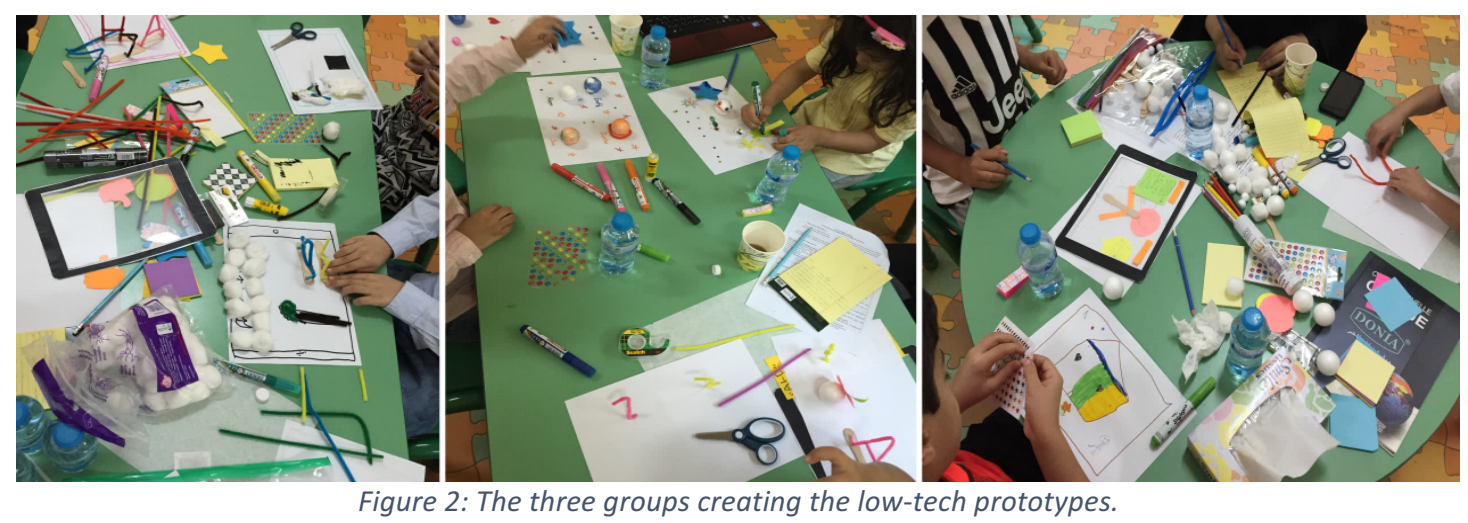

\subsection{Data Analysis}

Thematic analysis is a common data analysis method in qualitative studies with open-ended data, and a recommended method in generative design research [24]. The analysis process followed three techniques recommended by Lazar et al. [20] for the quality of the analysis. First was defining a group of specific items in order to look for while coding (Table 4).

Table 4: Defining a set of coding items.

\begin{tabular}{|l|l|}
\hline Item & Definition \\
\hline Interface & The user interface elements and application screen. \\
\hline Content & The augmented objects on the school textbook. \\
\hline Features & The actions and functions of the application. \\
\hline Style & The items that defines the theme of the AR textbook. \\
\hline
\end{tabular}


The second technique was asking questions about the data, which was done during the presentations, where the coders asked questions to the children for them to better explain their statements. Examples of questions asked about the data are listed in Table 5 with the participants' responses and photos from the presentations.

Table 5: Examples of questions about the data and responses.

\begin{tabular}{|c|c|c|}
\hline Question & Photo & Response \\
\hline $\begin{array}{l}\text { Is this the boy's house } \\
\text { behind him? }\end{array}$ & & $\begin{array}{l}\text { Yes, he comes out of the } \\
\text { house when we start the } \\
\text { application. }\end{array}$ \\
\hline What is the boy saying? & & $\begin{array}{l}\text { He is explaining the } \mathrm{AR} \\
\text { textbook. }\end{array}$ \\
\hline $\begin{array}{l}\text { How do you buy the } \\
\text { characters? } \\
\text { What is the register } \\
\text { button for? }\end{array}$ & & $\begin{array}{l}\text { By collecting credits from } \\
\text { winning the game. } \\
\text { It lets us create account with } \\
\text { our names and password. }\end{array}$ \\
\hline
\end{tabular}

The last technique was making comparisons of data sources. A constant comparison was done with the different data sources; the children's verbal presentations, the adult members' notes, and the generated artefacts in different stages of the sessions. After reading the data set from the white board and getting an overall impression, the adult members started to find the emerged patterns. 


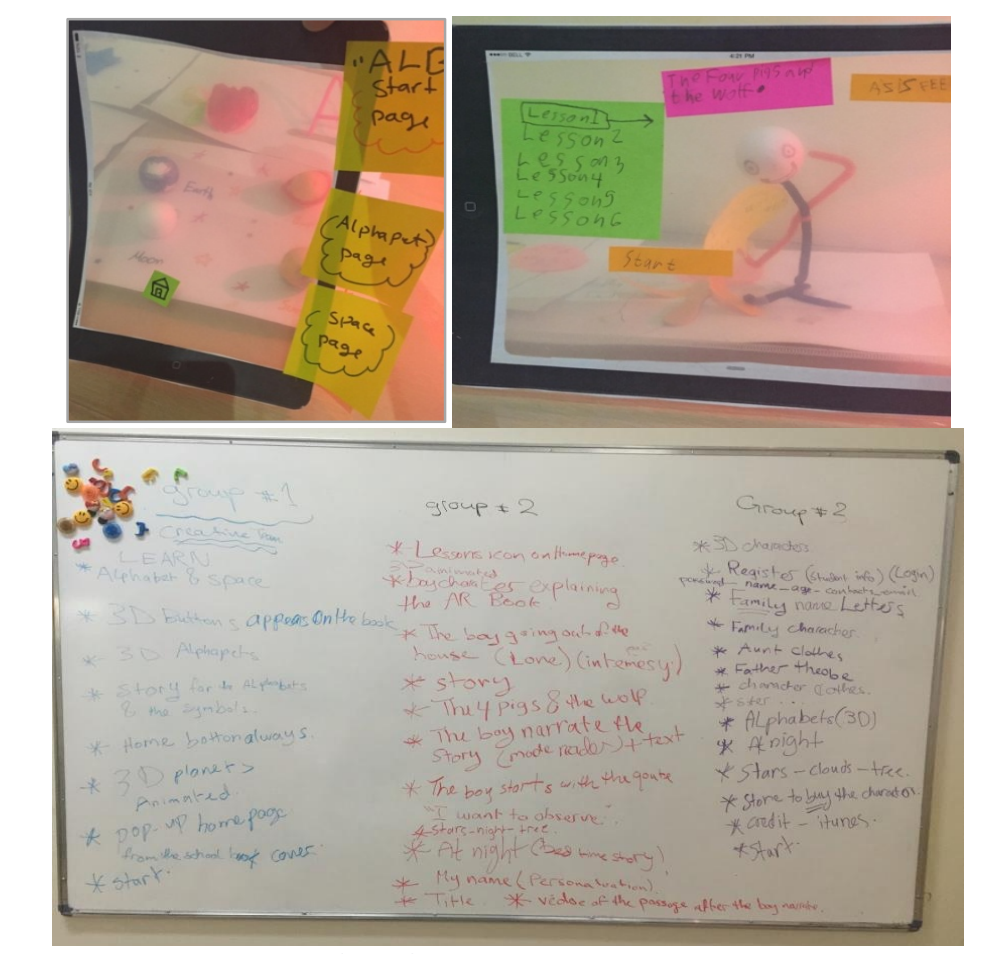

Figure 3: Top, the groups' artefacts; bottom, key ideas $n$ on the white boards.

The data set then grouped under the relative items defined earlier. For the second level of coding, the frequencies were highlighted where the themes started to emerge (Table 6). The researcher, with the help of the three coders, identified the design features for each group of data based on the highlighted frequencies and the broader category.

Table 6: Data set categorised to highlight frequencies.

\begin{tabular}{|l|l|}
\hline Category & Data \\
\hline Interface & $\begin{array}{l}\text { 3D buttons appear on the text book } \\
\text { Home button appears all the time } \\
\text { Start button after the pop-up } \\
\text { Icons of the lessons titles appears on the homepage } \\
\text { My name appears on the screen } \\
\text { Start button appears on the screen }\end{array}$ \\
\hline Content & $\begin{array}{l}\text { Story about the alphabets } \\
\text { Animated boy character explaining the AR textbook } \\
\text { 3D characters of the family } \\
\text { 3D alphabets of the first letters of the names of family members }\end{array}$ \\
\hline Features & $\begin{array}{l}\text { Pop-up home page when the school cover detected } \\
\text { The 4 pig and the wolf story narrated by the boy with written text } \\
\text { Video of the passage after the boy reads it } \\
\text { Register my name and password in the app } \\
\text { The app let us buy the characters by credits }\end{array}$ \\
\hline Style & $\begin{array}{l}\text { Learn alphabets and space } \\
\text { Animated 3D planets } \\
\text { The boy character comes out from his house at the beginning } \\
\text { The boy starts with the quote: "I want to observe!" } \\
\text { The boy comes out from his house at night looking at the stars and trees } \\
\text { Stars, clouds and trees appearing around the 3D letter }\end{array}$ \\
\hline
\end{tabular}


A principal issue identified at this stage shows that the children have similar views of the AR textbook. However, some different patterns did emerge from the data using thematic analysis with the three adult members. What is clear is that the low-level themes are aspects such as 3D, animation, home, family, and customisation. Whereas the high-level themes were identified as intimacy, Personalisation, and fun which can define the overall direction of designing the first AR textbook prototype. The initial prototype of the AR textbook was completely developed by the researcher considering the children's inputs.

The key design features implemented in the prototype can be concluded to the following, showing a demonstration of each from the first AR textbook prototype after development by the researcher:

- The end of the textbook activity will result in a reward card which is an AR marker that can be displayed by the tablet. The reward card will play the animation of the selected object, but if more than one student share their cards, an enhanced version of the animation will play. This feature represents a unique AR collaborative experience which supports the diversity between the classroom students and give each student a chance to participate. It was informed by the resulted theme of customisation and personalisation, in which it can be exchanged by the students to display different $3 \mathrm{D}$ scenes, and can be joined together to complete the $3 \mathrm{D}$ objects of the animation scene.

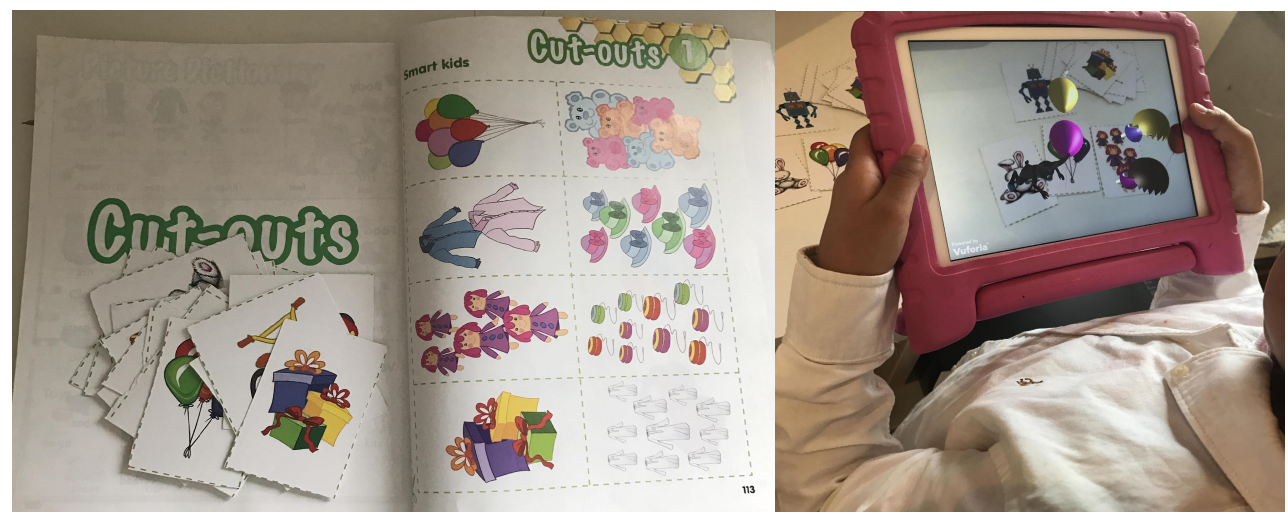

Figure 4: The reward cards as AR markers for a collaborative AR experience.

- Using the textbook as the main interface, with the only change being made is adding the AR markers into the textbook to be tracked by the AR application. This feature allows for the integration of $\mathrm{AR}$ in the regular curriculum not concerning with creating an educational content since the printed textbook is designed by the 
curriculum experts. In the textbook, students see the pictures, but with the AR textbook they will visualise the object animated and the characters come to life. This feature also considers the learning aspect since it provides immediate digital content related to the printed content of the textbook, and was informed by the resulted theme of fun, using 3D animation for the textbook activities. The theme of intimacy also informed the 3D content of the AR textbook in the modelling of the 3D characters.
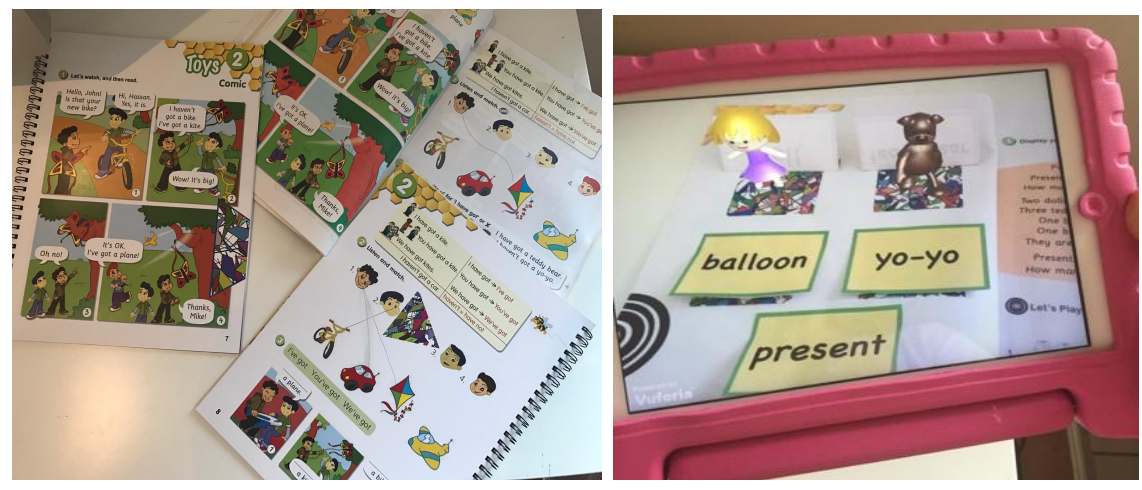

Figure 5: The regular textbook, and the AR textbook showing same content with added AR markers.

- To allow flexibility, the AR textbook can be applied in three settings where students can share the control, or use the AR textbook by their own to learn individually. This feature is supported by the use of tablet as the main interface for the textbook based AR.
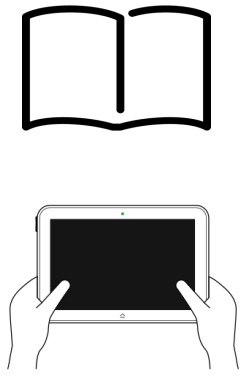

a) Individual AR textbook experience.
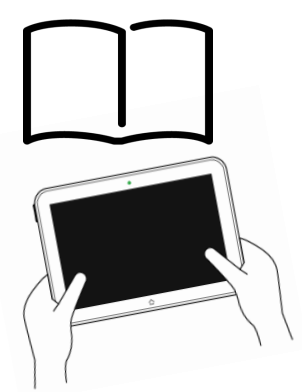

b) More than one student can share the same tablet to display the AR scene.

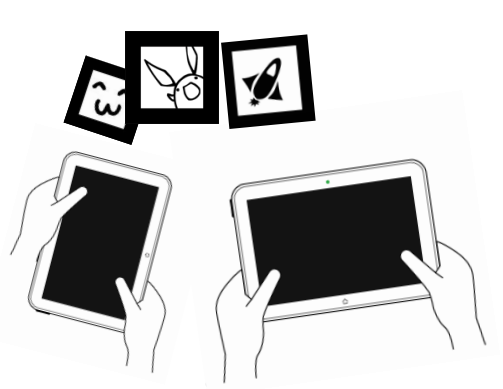

c) One or more students share and display the AR reward cards.

Figure 6: AR textbook can be used in different settings.

The high-fidelity prototype in this stage represents an intermediate prototype to be used in the next formative evaluation. The key design features on that prototype were informed by the themes resulted from the low-tech prototyping and the concepts of the ELU. 


\section{COOPERATIVE INQUIRY AND LAYERED ELABORATION STUDY}

\subsection{Materials}

Table 7 illustrates the probes, toolkits and the prototype used in this study, and figure 7 shows the toolkits and the prototype used for these sessions of CI critiquing and layered elaboration.

Table 7: Planning the evaluation sessions based on Sanders and Steppers' comparison table.

\begin{tabular}{|c|c|c|c|}
\hline & Probes & Toolkits & Prototype \\
\hline What is made? & $\begin{array}{l}\text { Different Color post-it } \\
\text { notes. }\end{array}$ & $\begin{array}{l}\text { Clip- boards, binder clips. } \\
\text { write-on clear } \\
\text { transparency film. } \\
\text { Pens and markers. }\end{array}$ & $\begin{array}{l}\text { A completed prototype of } \\
\text { AR textbook. }\end{array}$ \\
\hline Why? & $\begin{array}{l}\text { Adult participants in } \\
\text { each group write } \\
\text { children's ideas and } \\
\text { suggestions on the } \\
\text { post-it notes, where } \\
\text { each color represents } \\
\text { the ELU aspects. }\end{array}$ & $\begin{array}{l}\text { The hanger and the trans } \\
\text { are used for layered } \\
\text { elaboration. While the } \\
\text { post-it notes are used to } \\
\text { write their likes, dislikes } \\
\text { and suggested design ideas } \\
\text { in separate colours. }\end{array}$ & $\begin{array}{l}\text { To evaluate the current } \\
\text { prototype based on the } \\
\text { concepts of the ELU } \\
\text { framework. }\end{array}$ \\
\hline $\begin{array}{l}\text { What is it made } \\
\text { out of? }\end{array}$ & $\begin{array}{l}\text { Adult facilitate the } \\
\text { abstract terms of } \\
\text { collaborative } \\
\text { experience to children } \\
\text { through asking } \\
\text { different open-ended } \\
\text { questions to provoke } \\
\text { responses. }\end{array}$ & $\begin{array}{l}\text { Pieces of UI elements, } \\
\text { different sizes of post-it } \\
\text { notes, tracing papers, pipe } \\
\text { cleaners, clay, strings, } \\
\text { scissors, glue, erasable } \\
\text { coloured markers, and } \\
\text { pencils. }\end{array}$ & $\begin{array}{l}\text { The AR textbook } \\
\text { prototype includes the } \\
\text { tablet application and the } \\
\text { redesigned school } \\
\text { textbook, with the image } \\
\text { marker cards. }\end{array}$ \\
\hline $\begin{array}{l}\text { Who } \\
\text { conceives? }\end{array}$ & $\begin{array}{l}\text { The researcher } \\
\text { provides the toolkits } \\
\text { and the prototype for } \\
\text { the three groups and } \\
\text { guide the data } \\
\text { collection sessions. }\end{array}$ & $\begin{array}{l}\text { The researcher provides } \\
\text { the toolkits to the } \\
\text { participant groups. The } \\
\text { process is facilitated and } \\
\text { guided by the researcher } \\
\text { and adult members. }\end{array}$ & $\begin{array}{l}\text { The researcher developed } \\
\text { the prototype based on the } \\
\text { co-designers' ideas and the } \\
\text { result of the low-tech } \\
\text { prototyping session in the } \\
\text { first study of this research. }\end{array}$ \\
\hline Who uses? & $\begin{array}{l}\text { The AR textbook } \\
\text { prototype is provided } \\
\text { to each group to } \\
\text { experience where } \\
\text { adult members in each } \\
\text { group take notes of the } \\
\text { dialogue related to the } \\
\text { children's ideas and } \\
\text { suggestions. }\end{array}$ & $\begin{array}{l}\text { The children with the adult } \\
\text { members use them for the } \\
\text { formative evaluation. }\end{array}$ & $\begin{array}{l}\text { The children groups } \\
\text { experience the AR } \\
\text { textbook for the purpose } \\
\text { of evaluation. }\end{array}$ \\
\hline
\end{tabular}




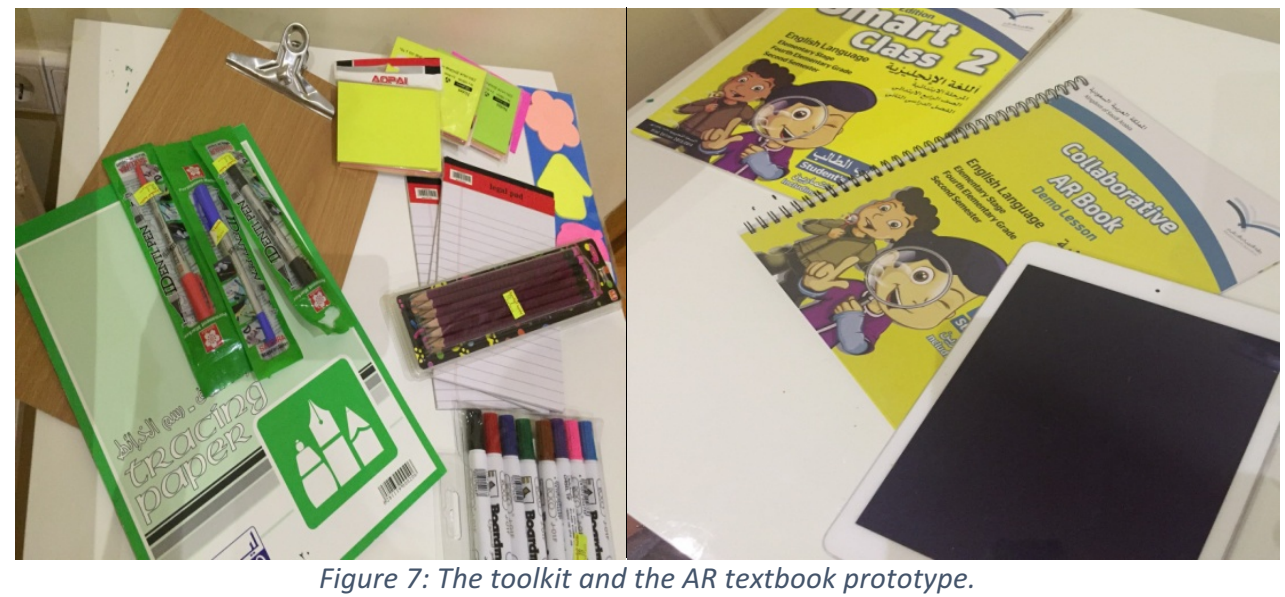

Cooperative Inquiry Critiquing was used to collect data about the current prototype from the different aspects of collaborative experience, learning and usability. Whereas the layered elaboration was selected as a generative method to collect more data focusing on the collaborative experience specifically since it's the main aim of the design.

\subsection{Procedure}

The session started with the children experimenting the AR textbook. The first spontaneous impression when the $3 \mathrm{D}$ object popped up from the book was significantly surprising to them, while they reacted with liking expressions (Figure 8).

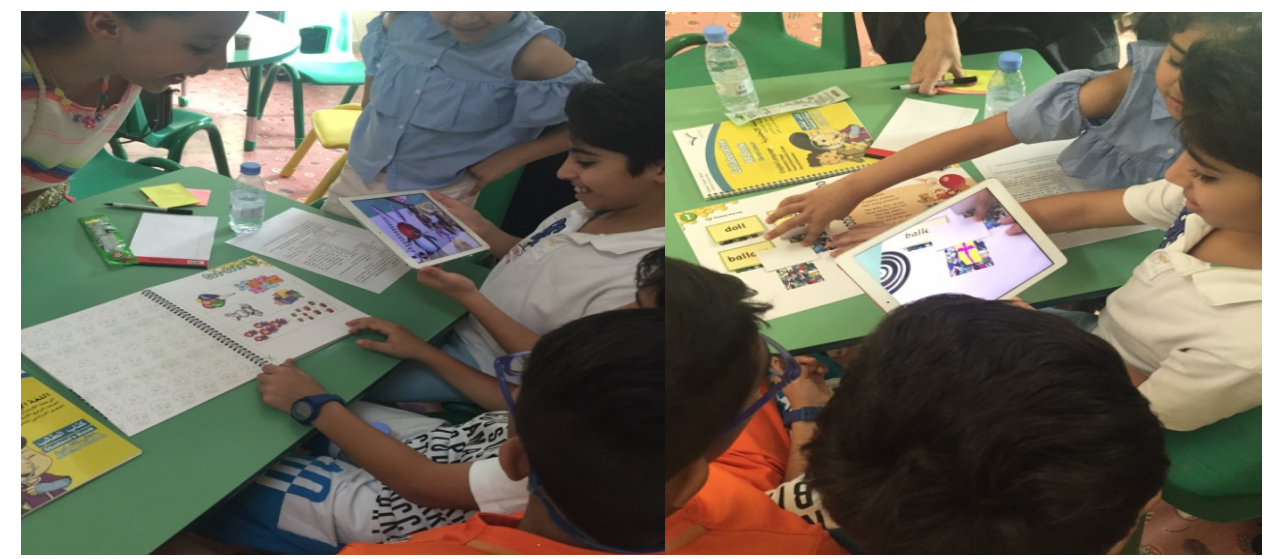

Figure 8: Children reaction when experiencing the AR Book prototype.

After a short experiment of exploring the design features of the prototype, the CI critiquing started as the researcher asked the groups to write their likes, dislikes, and suggested design ideas on the colored post-it notes while continuing experimenting the AR textbook (Figure 9). The adult members in each group were facilitating this process in which they write children statements on the colored post-it notes based on the categories of like, dislike, suggested design idea. They were asking open ended question in order for children to elaborate on their ideas and writing it on the notes. The researcher then asked the groups to 
do the same process again focusing on the aspects of collaborative experience, learning and usability. The adult member in each group asks the children questions of how the prototype can be improved related to these aspects. This stimulated the child members thinking to suggest more ideas in order to collect as much data as possible about these specific concepts.

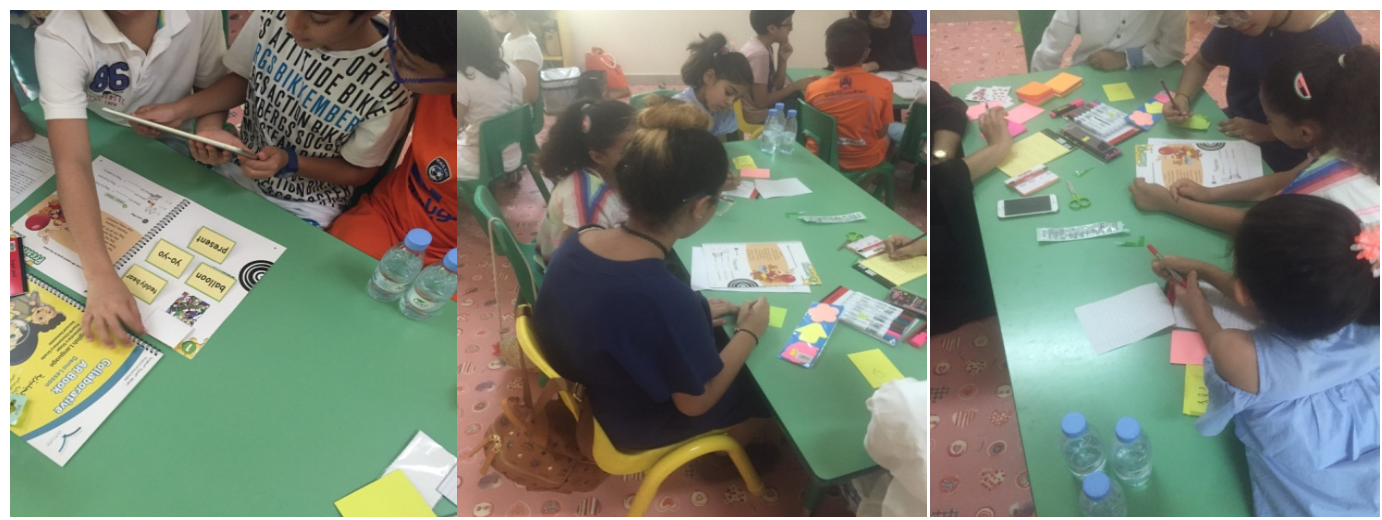

Figure 9: The group members in the cooperative inquiry critiquing session.

The second session applied the layered elaboration technique to collect more data focusing on the collaborative experience only. The session started by giving one group a clipboard with white paper and a marker, and asked them to draw their final idea on how to improve the collaborative experience of the AR textbook prototype. The group members already had some ideas to elaborate on, so the adult member guided the discussion and facilitated the process to develop a shared design idea to be drawn on the clipboard paper. The group then presented a brief overview of their design ideas to the whole team, and then pass the clipboard to the next group. The process repeated to the third group, in which each group overlaid a transparency sheet on the clipboard, and adult member reads a description of the current storyboard then asked how it could be improved (Figure 10). Once all groups have had a chance to design a presentation of their ideas, the final elaborated idea were discussed with the adult members to be written on the post-it notes and placed on the white board with the suggested design ideas category.

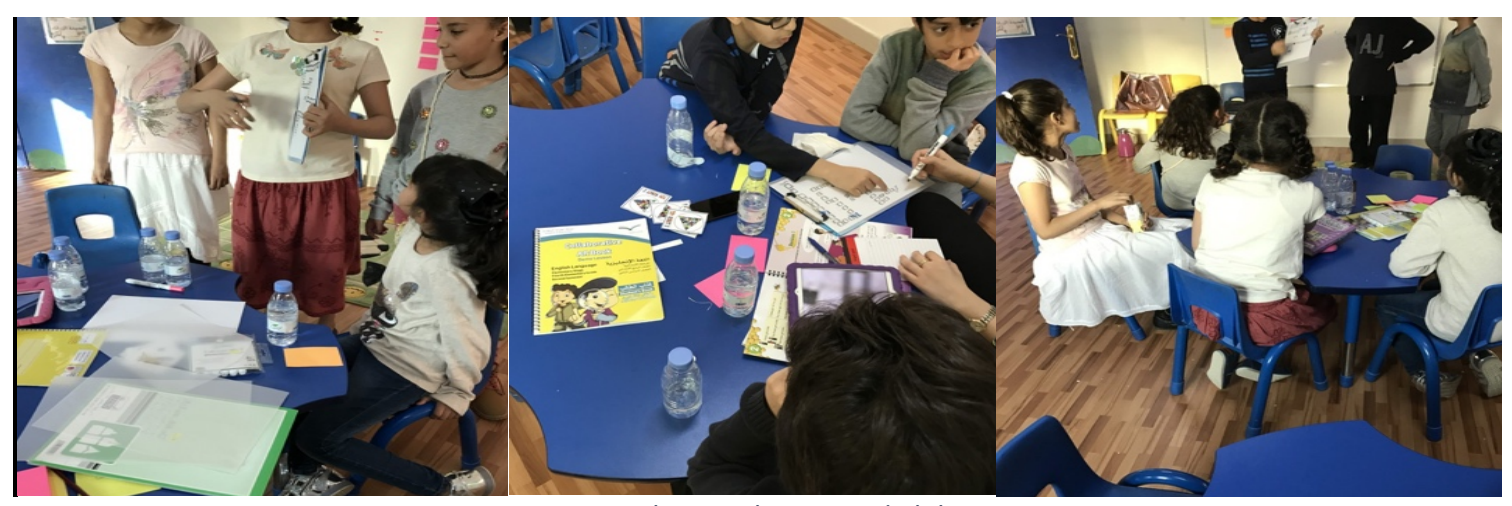

Figure 10: Group members in the Layered Elaboration session. 


\subsection{Data Analysis}

The analysis session involved the adult members using thematic analysis to elucidate the groups elaborated result on the prototype, in addition to the data collected from the CI critiquing. The procedure started with a set of text-based data which is represented by the notes collected on the white board from the two sessions i.e. (CI critiquing and layered elaboration). The data set was initially categorised based on the likes, dislikes, and suggested design ideas by the color post-it notes (Figure 11). The adult members started the coding process by reading the transcripts and writing their interpretations of the interesting quotes taken from the children's own words on their notes. The adult team then discussed the interpretations of each transcript to agree on one concept to be written on the top of the transcript of the child statement. Moving the different interpretations into a higher level of conceptualisation was based on the concepts of collaborative experience, learning and usability. Based on the new interpretations, the data set was re-categorised in relation to the collaborative experience, learning, or usability that are identified earlier as the classification concepts [20].

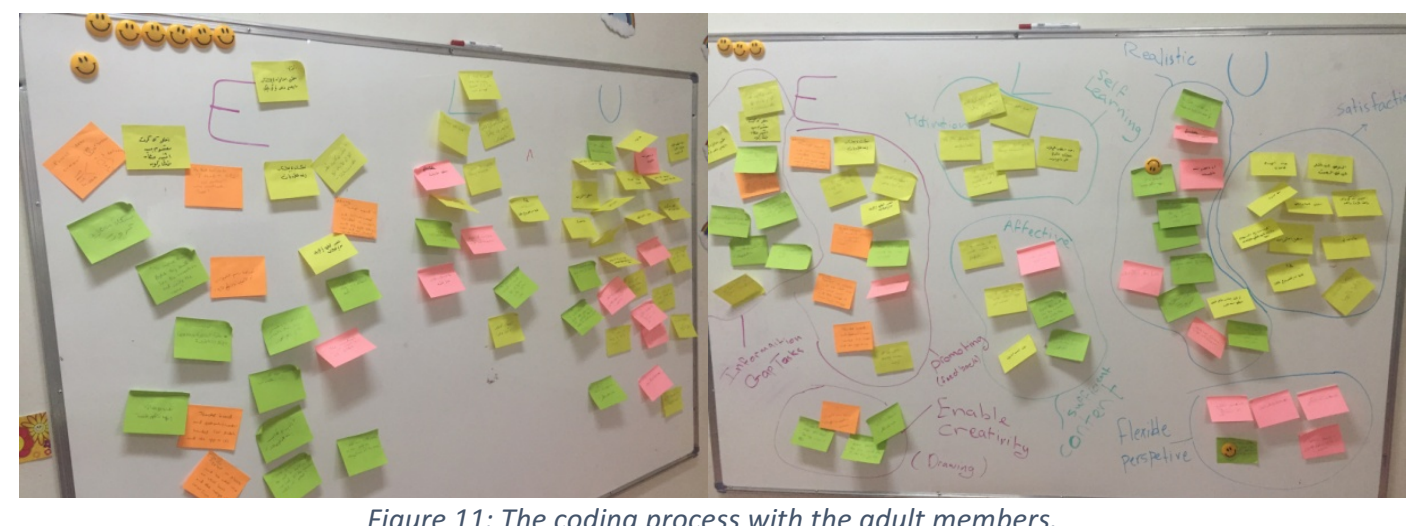

After reading the transcripts again, and adult members discussed their insights, and reflect on the analysis specific patterns started to emerge. The researcher guided the discussion to ensure everyone understand each other insights. The researcher then with the help of the three coders, identified the design features informed by each group of data. Posting all the notes on the white board was a form of visualisation in which every member can follow, reflect on, and contribute to the analysis process, and they can be easily moved and rearranged which were useful in organising the data set. The data from the child members led to ideas and insights in low level analysis. Whereas the wider concepts emerged after the data interpretation into more conceptualisation level. The result of the analysis gave insights of future design features that informed the next iteration of the design. 


\section{FINDINGS}

This formative evaluation has resulted in identifying the key design features that can be implemented in school textbooks for a collaborative AR experience. These unique features are basically related to the aspects of collaborative experience, learning and usability. A clarification of each feature is introduced, as well as a demonstration from the refined AR textbook after developing a second high-fidelity prototype.

- Joint AR markers: Separating the AR marker into the edges of two textbooks so it will not work until the textbooks are joined, and therefore the activity cannot be done by one student. This feature encourages students to join each other to complete the AR marker in order to be tracked by the camera and display the AR scene. Students therefore will use communication cues to do the textbook activities together, creating a collaborative learning experience unique to AR.
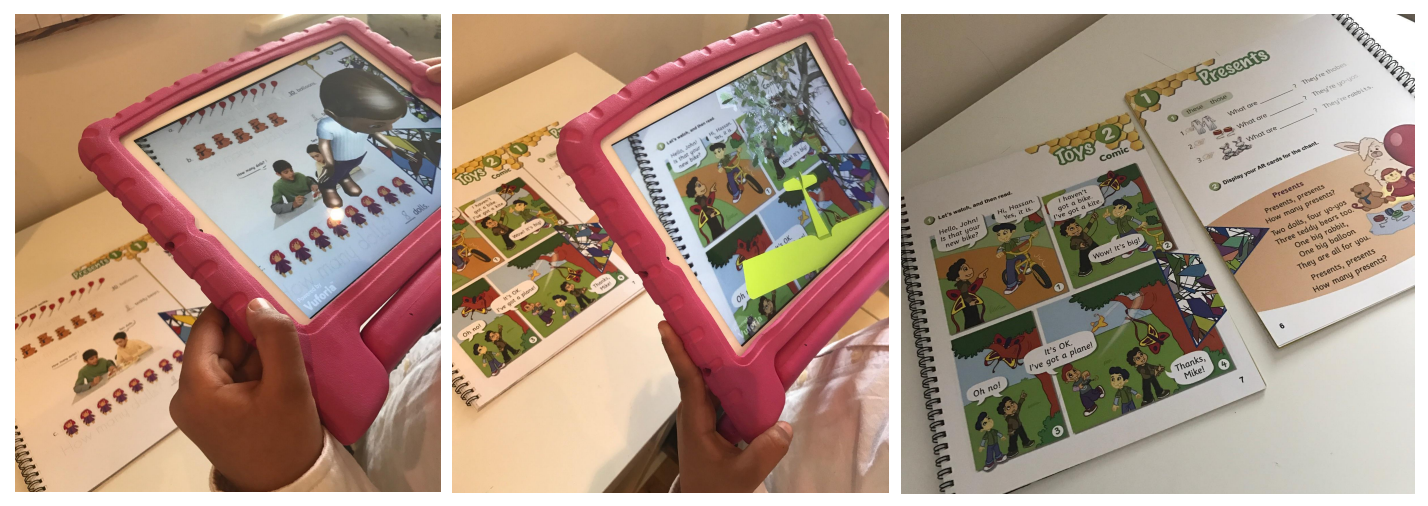

Figure 12: The joint AR markers.

- AR reward cards: This feature uses AR markers in cards that can be collected as a rewarding feedback. It supports collaboration where students want to join each other to do the activity and collect a card. It also supports personalisation where students can exchange their cards to display the enhanced version of the AR content. This feature was informed by the first study but the idea was further improved to be used as joint AR markers where one card can display the AR content but if it was placed beside another card it displays a completed and enhanced AR content of the textbook. 


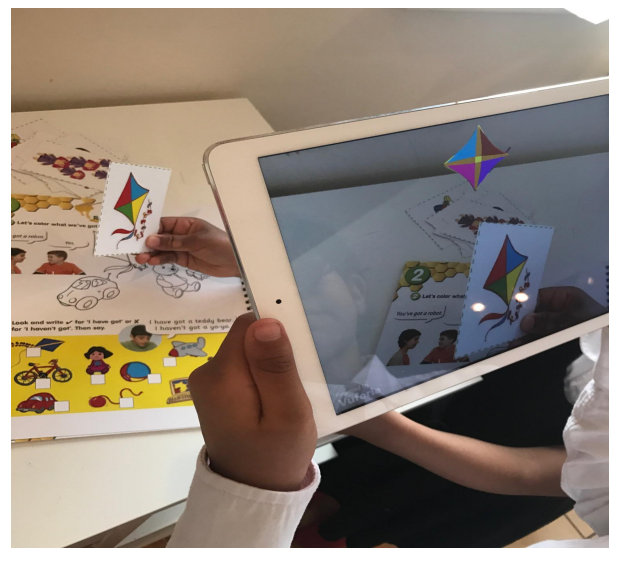

Figure 13: The AR Reward Cards.

- Textbook images and content as AR markers and AR scenes: Using the images of the textbook to design the AR image markers. Also, using the activities that are already in the textbook to design the AR scenes accordingly. For example, the bicycle in the textbook in figure 14 is scanned and implemented in the application as AR marker to display the animated 3D bicycle when displayed by the tablet, by using the affordance of markerless AR. This supports the integration of AR in the actual textbook content.

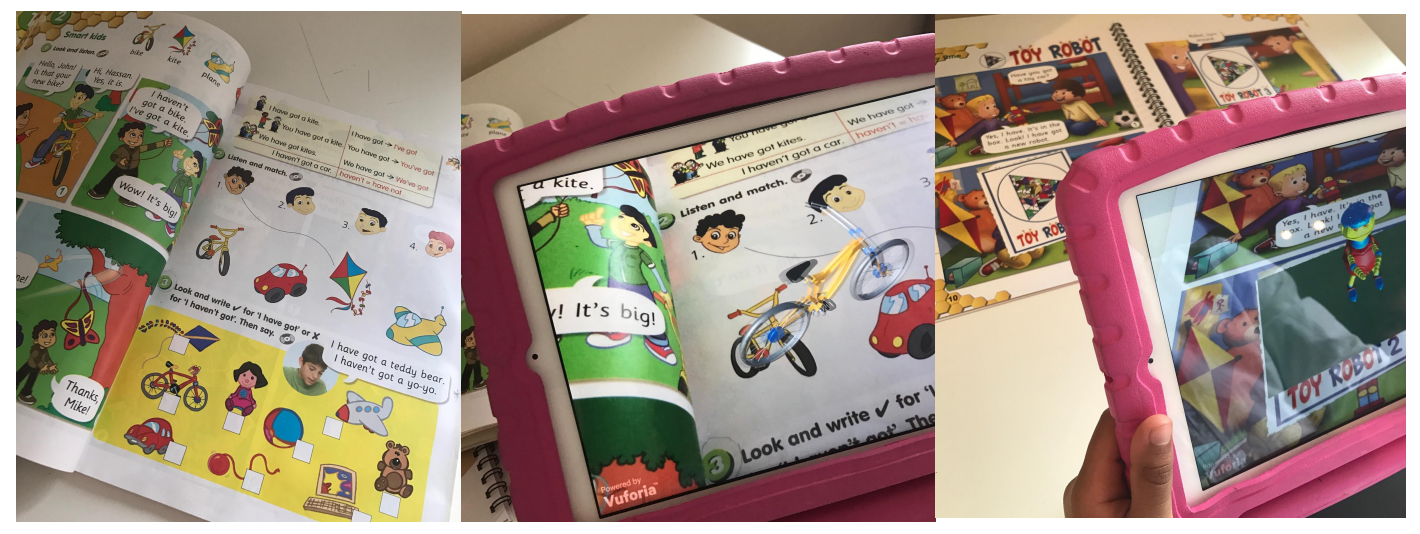

Figure 14: The images in the textbook as AR markers, and the AR scene based on the printed content of the textbook.

- Interactive AR display: This feature enables students to interact with the 3D model through the tablet touch-screen generating different sound and visual effects for more engagement in the collaborative learning experience. This feature provides students engagement with the learning material as well as engagement with other students in which it supports the collaborative experience. 


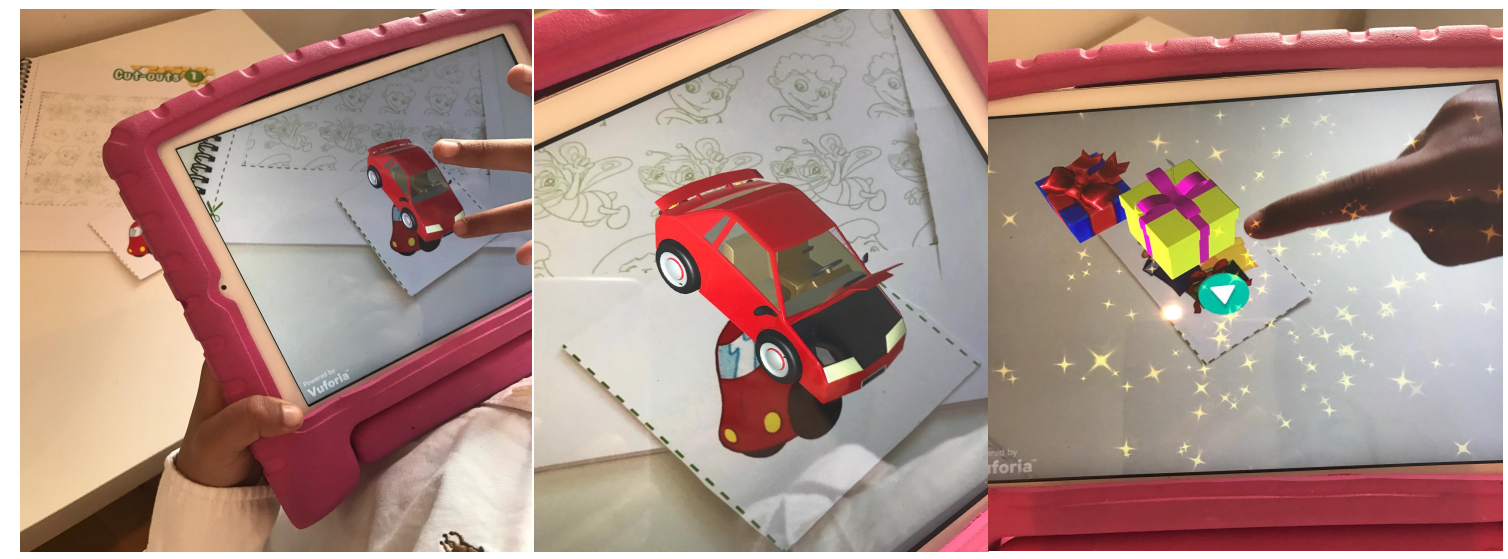

Figure 15: The interactive AR display.

The proposed outcome of the AR textbook is based on a textbook for the English subject of Saudi Arabian primary school's curriculum. This textbook was used as a sample for the purpose of the study, to demonstrate how AR can be embedded in a school curriculum, through the identification of the design features that can be integrated into the textbook for AR collaborative learning experience. It is agreed that primary schools will mostly benefited from this recent technology because the level of the language skills of the Saudi Arabian primary schools' students varies from one student to another in the same grade, in which the collaborative interaction that can be afforded by AR is likely to help children to get advantages from each other and increase chances of co-construction of knowledge. The other important motivation is that a growing number of primary schools in Saudi Arabia have introduced the iPad in their classrooms, and are looking for applications that actively support the learning environment. Regardless of a student's socio-economic, children in Saudi Arabia having their own mobile devices is notably increasing.

Even though this study uses the Saudi primary schools' textbook, it can be noted from the practical outcome that these design features can be applicable in other textbooks intended to use the affordances of AR. The collaborative design feature of Joint AR markers for example can be applied in any textbook where the AR marker can be divided at the edge of the textbook pages to encourage students to connect their textbooks together in order to display the AR content that is related to the textbook activities. In the same sense the feature of Textbook images and content as AR markers and AR scenes can be applicable in other textbooks to allow the integration of AR in the school curriculum depending on the content of the specific textbooks. The identified design features offer useful guidelines for designing collaborative AR textbooks for a variety of learning contexts. 


\section{DISSCUSION}

This research applied the common methods of CCI in the context of AR for children. Even though co-design is considered as a common approach in the CCI community, when looking at practical implications as a method, a little work has considered how children can be involved, and how their ideas are included and represented. Until recently, studies of AR for children have only involved children when the final outcome has been developed, without their involvement to actually inform the early design prototypes [25]. The originality of this research represented in involving the primary school's children in the design of the AR textbook using cooperative inquiry techniques. The other aspect of originality is in showing how AR can be integrated in the school's curriculum for a collaborative AR experience that considers learning, and usability features. It is hoped that the documentation of the conducted studies will contribute guidelines for co-designing a collaborative AR textbook, as well as suggesting a CCI perspective in the development of AR application for children.

The co-design method has its' own limitation when involving children in the research, which has raised lots of challenges in managing the time and efforts in each session. It also costs more than the traditional methods since it requires toolkits and prototypes. Also, the qualitative data, and especially the data gathered from such co-design sessions, is messy. One example of how to overcome this issue is having a specific set of protocols for all the participants to follow. This ensures consistency in how data is collected and documented which helped in managing the analysis. In addition, the process in this research followed a systematic pattern borrowed from previous studies of CCI and HCI, for example, the comparison between the different types of data sources, and using the ELU concepts as a classification framework for categorising the data, searching for patterns, and determining how will they would eventually fit into the prototype.

On the other hand, it was noted from the studies that the children participants are familiar with tablet applications, and easily understand the idea of the AR applications. They were surprisingly interactive and information active in the co-design sessions. The argument that children are natural partners for co-design is extremely supported. The child members had participated with interesting design ideas that often have significant connections. The adult members were also affective in their different roles of facilitator, note-takers, and coders. The males and females were working together in the groups, and it was recognised that the child male participants were more information active and enthusiastic to participate in the co- 
design session than the child female participants. Also, the child members who happened to know each other before the sessions were more productive compared to others just met in the study. However, the nature of co-design sessions as well as the collaborative AR textbook activities, helped the group members to build a team relationship, that facilitated every child's active involvement.

The experience of the low-tech prototyping phase showed that it would be better to separate the data analysis session to be in a different day from the data collection session. As stated earlier, the children were interactive and enthusiastic to express their ideas, and each child member was expressing the idea once it comes on his mind. This occasionally interrupt other child statements, or the note takers, because they were speaking at the same time. The adult members therefore were trying to have conversations with each child and asked questions to ensure all children ideas explained and documented. Giving sufficient time for the data collection session ensures that no idea has been missed, and child participants had the time to think, express, and elaborate on their ideas. This was a critical factor of the next evaluation study when even a greater amount of time would need to be allocated.

Although the research involved participants from different academic backgrounds, they all share the same ideological background that might affect their worldview, which in turn might affect their interpretation and analysis of the data. Acknowledging that point means that the outcome of this research will be specific to similar communities that share the same geographical location and ideological background. This could, theoretically, bind up the acquired knowledge to a narrower context. However, being mindful of that consideration allows other researchers in the field to understand where particularly these outcomes might be influenced, and how to embed these outcomes in different added locational contexts. The studies were clearly reported with the objective of allowing another investigator to replicate the procedures in a verifiable fashion. It can be of benefit to researchers and design practitioners who seek to use co-design with children for AR applications.

It can be argued that AR textbook promotes a bring-you-own-device (BOYD) type of setting, which has its own limitations such as promoting a status gap between students, lack of social communication between groups/individuals, and lack of cross-platform. However, the purpose of the proposed AR textbook is to support collaborative learning experience, because AR has been proved to support collaborative learning, and can be used to create a unique collaborative experience as mentioned earlier [3], [4], [5], [6]. Therefore, using the 
affordances of AR to design a collaborative AR textbook can promote the social interaction between students, in which it encourages them to join their textbooks in order to do the activities together as shown in the joint AR markers and $A R$ reward cards features. Other common misunderstanding is that technology is considered as the driver of the teaching and learning activities and not as the enabler [26], however, the primary purpose of integrating $\mathrm{AR}$ into the curriculum is to enhance the learning experience focusing on the collaborative aspect in this context. In addition, the proposed AR textbook can be used in different scenarios as shown in figure 6 , where two or more students share the display of one tablet because the $3 \mathrm{D}$ content can be displayed from different perspectives. Informed by the belief that learning is inherently a social activity, it is argued that the unique attributes of handheld applications facilitate learner collaboration, and support knowledge sharing [27]. Using the school textbook combines the benefits of the paper ergonomics and the benefits of the tablet interface. Nevertheless, AR have developed over the past few years to such an extent to be used as a cross platform application, and that many of these concerns have been addressed.

\section{CONCLUSION}

This paper has identified key design features of the AR textbook for collaborative learning experience, as well as presenting the co-design process of the proposed prototype. The identified design features are built in a practical outcome of an AR textbook based on an actual textbook of primary schools in Saudi Arabia. The originality of this research is in involving the primary school's children in the design of this AR textbook using cooperative inquiry techniques. The other aspect of originality is in showing how AR can be integrated in the school's curriculum to for a collaborative AR experience that takes into account learning, and usability features. The proposed outcome demonstrates a sample of how these features can be integrated in a school textbook for different curriculums.

In conclusion, this paper contributes to answering the questions of what are the design features of the collaborative AR that can be embedded in a school textbook, and also of how co-design with and for children can be applied in the context of AR. The documentation of the sessions' planning, data collection procedure, and analysis process provides the answer of this question. Whereas the practical outcome of the AR textbook prototype demonstrates the key design features, that answers the first research question. Finally, this paper can be considered as an attempt to bridge the gap between AR and CCI community by applying the common methods of CCI in the context of AR for children. 


\section{ACKNOWLEDGEMENTS}

This work was sponsored by Princess Nourah Bint Abdulrahman University, and the Saudi Arabian Cultural Bureau in London. Thanks for Alrowad International School for the kind permission to conducting this study.

\section{REFERENCES}

[1] H. Kaufmann, Collaborative augmented reality in education, Keynote Speech Imagina Conf. (2003).

[2] J.R.S. Javier Barbadillo, Nagore Barrena, V'ictor Go ni, Collaborative E-Learning Framework for Creating Augmented Reality Mobile Educational Activities, Springer International Publishing, Cham, 2014. doi:10.1007/978-3-319-13102-3.

[3] K.R. Bujak, I. Radu, R. Catrambone, B. MacIntyre, R. Zheng, G. Golubski, A psychological perspective on augmented reality in the mathematics classroom, Comput. Educ. 68 (2013) 536-544. doi:10.1016/j.compedu.2013.02.017.

[4] S. Lukosch, M. Billinghurst, L. Alem, K. Kiyokawa, Collaboration in Augmented Reality, Comput. Support. Coop. Work. (2015). doi:10.1007/s10606-015-9239-0.

[5] A. Morrison, A. Mulloni, S. Lemmelä, A. Oulasvirta, G. Jacucci, P. Peltonen, D. Schmalstieg, H. Regenbrecht, Collaborative use of mobile augmented reality with paper maps, Comput. Graph. 35 (2011) 789-799. doi:10.1016/j.cag.2011.04.009.

[6] A. Dünser, E. Hornecker, Lessons from an AR book study, in: Proc. 1st Int. Conf. Tangible Embed. Interact. - TEI '07, ACM Press, New York, New York, USA, 2007: p. 179. doi:10.1145/1226969.1227006.

[7] M. Dunleavy, C. Dede, Augmented reality teaching and learning, ... Res. Educ. Commun. .... (2014) 134.

[8] N. LeJeune, Critical components for successful collaborative learning in CS1, J. Comput. Sci. Coll. 19 (2003) 275-285.

[9] R. Hoda, A. Henderson, S. Lee, B. Beh, J. Greenwood, Aligning technological and pedagogical considerations: Harnessing touch-technology to enhance opportunities for collaborative gameplay and reciprocal teaching in NZ early education, Int. J. Child-Computer Interact. 2 (2014) 48-59. doi:10.1016/j.ijcci.2014.06.001.

[10] H.-K.K. Wu, S.W.-Y.Y. Lee, H.-Y.Y. Chang, J.-C.C. Liang, Current status, opportunities and challenges of augmented reality in education, Comput. Educ. 62 (2013) 41-49.

doi:10.1016/j.compedu.2012.10.024.

[11] A. Druin, Cooperative inquiry: Developing new technologies for children with children, in: Hum. Factors Comput. Syst., ACM Press, 1999: pp. 592-599. doi:10.1145/302979.303166.

[12] A. Druin, M.L. Guha, J.A. Fails, Cooperative Inquiry revisited: Reflections of the past and guidelines for the future of intergenerational co-design, Int. J. Child-Computer Interact. 1 (2013) 14-23. doi:10.1016/j.ijcci.2012.08.003.

[13] B. Xie, A. Druin, J. Fails, S. Massey, E. Golub, S. Franckel, K. Schneider, Connecting generations: developing co-design methods for older adults and children, Behav. Inf. Technol. 31 (2012) 413-423. doi:10.1080/01449291003793793.

[14] G. Walsh, A. Druin, M.L. Guha, E. Foss, E. Golub, L. Hatley, E. Bonsignore, S. Franckel, Layered elaboration: A new technique for co-design with children, in: Proc. 28th Int. Conf. Hum. Factors Comput. Syst. - CHI '10, ACM Press, New York, New York, USA, New York, USA, 2010: p. 1237. doi:10.1145/1753326.1753512.

[15] K. Vaajakallio, J. Lee, T. Mattelmäki, It has to be a group work!: co-design with children, ... Interact. Des. Child. (2009) 3-6. doi:http://doi.acm.org/10.1145/1551788.1551843.

[16] E. Sanders, P.J. Stappers, Probes, toolkits and prototypes: three approaches to making in codesigning, CODESIGN-INTERNATIONAL J. COCREATION Des. ARTS. 10 (2014) 5-14.

doi:10.1080/15710882.2014.888183. 
[17] E.B.-N. Sanders, P.J. Stappers, Co-creation and the new landscapes of design, CoDesign. 4 (2007) 5-18.

[18] A. Melonio, R. Gennari, Co-Design with children: the State of the Art, (2013).

[19] G. Walsh, E. Foss, J. Yip, A. Druin, FACIT PD: a framework for analysis and creation of intergenerational techniques for participatory design, in: Proc. SIGCHI Conf. Hum. Factors Comput. Syst. - CHI '13, ACM Press, New York, New York, USA, 2013: p. 2893. doi: $10.1145 / 2470654.2481400$.

[20] J. Lazar, J.H. Feng, H. Hochheiser, Research Methods in Human-Computer Interaction, 2010th ed., Wiley Publishing, 2010.

[21] L. McKnight, J. Read, PLU-E: a proposed framework for planning and conducting evaluation studies with children, in: Proc. 25th BCS Conf. ..., 2011: pp. 1-6.

[22] P. Markopoulos, J.C. Read, S. MacFarlane, J. Hoysniemi, Evaluating Children's Interactive Products: Principles and Practices for Interaction Designers, Morgan Kaufmann, 2008.

[23] A. Strauss, J. Corbin, Basics of Qualitative Research, 2008. doi:10.4135/9781452230153.

[24] J. Preece, H. Sharp, Y. Rogers, Interaction Design: Beyond Human-Computer Interaction, 4th ed., John Wiley \& Sons, 2015.

[25] J.C. Read, D. Fitton, M. Horton, Giving Ideas an Equal Chance : Inclusion and Representation in Participatory Design with Children, in: IDC, 2014: pp. 105-114. doi:10.1145/2593968.2593986.

[26] T.H. Brown, L.S. Mbati, Mobile learning: Moving past the myths and embracing the opportunities, Int. Rev. Res. Open Distance Learn. 16 (2015) 115-135. doi:10.1017/CBO9781107415324.004.

[27] B. Patten, I. Arnedillo Sánchez, B. Tangney, Designing collaborative, constructionist and contextual applications for handheld devices, Comput. Educ. 46 (2006) 294-308. doi:10.1016/j.compedu.2005.11.011. 